\title{
Neoliberalism, NAFTA, and Dehumanization: The case of femicides in Ciudad Juárez
}

\author{
Denisa Krásná and Sagar Deva
}

\section{Introduction}

Today, we live in an uncertain world where long-held assumptions about the progress and advancement of human civilization along particular lines are being challenged. The assumptions of increased global prosperity under a Western-led liberal democratic order and most famously enunciated in Francis Fukyama's "The End of History," now seem to be increasingly under challenge. While the size of the overall global economy has unarguably increased, the distribution of that wealth has become increasingly concentrated within the top one percent of the global population. Inequality has grown exponentially in both the developing and the developed world since 1980, and it is now the case that the top $1 \%$ of the world's population own $50 \%$ of the world's wealth (Neate 2017).

It is the contention of this article that this transfer of wealth from the lower economic echelons of global society to the top has consequences which are not just economic but definitively human, reducing the existence of human beings, particularly women (who are naturally disadvantaged) by such a system, to commodities, threatening not only their economic but human security. To make this contention, this paper will take as its key case study the effects of NAFTA on the security of women in Ciudad Juárez, in particular, those who work in the so-called maquiladoras. However, before undertaking this case study, which will form the mainstay of this piece, this article will offer a brief introduction to global neoliberalism in order to provide something of a foundation on which the main case study of the article can build.

\section{Capitalism, Neoliberalism, and Dehumanization}

"Neoliberalism" is a word often used to describe the underpinning economic philosophy that has dominated the international system and its related institutionalization over the last 40 or 50 years. Neoliberalism is, as George Monbiot argues, a philosophy that sees competition as the "defining component of human relations," and that the active and uncontrolled dynamics of the market provide the best model for human prosperity (2016). Neoliberalism emerged dominant in the 1980s from the earlier predominant philosophy of Keynesianism, which advocates for a form of capitalism but also for the free market to be controlled by political and institutional forces to protect social, environmental, or other human causes (Palley 2005:1-5).

While the idea of a "pure" form of capitalism was advocated as early as 1947 by Hayek, it was in the early part of the Thatcher/Reagan era that this philosophy became dominant and became espoused at a more global level (Hayek 1980). At its core, the idea of neoliberalism focused on the full liberation of the free market and the removal or minimal use of government intervention in the market to promote or protect social causes such as employment, housing, or healthcare (Harvey 2007: 24-34). The assumption made by advocates of such a system is 
that the intrusion of external or governmental forces into the market reduced its inefficiency, therefore reducing “economic growth," or overall output (Rodrik 2017: 6-10).

Unsurprisingly, then, within this paradigm, there has been a substantive power shift away from states and towards multinational corporations as the dominant units of global capitalism and the key "profiteers" from any such move. Multinational corporations have benefited in two key ways from the massive spree of market liberalization unleashed by neoliberalism. Firstly, the removal of tariffs and regulatory protections from local industries opened up substantial new markets in developing countries for corporations to sell their products. Secondly, the liberalization of trade and the removal of barriers allowed multinational corporations to scour the globe for countries where goods could be produced at the lowest cost (Kostova, Kendall, and Dacin 2008: 994-1006). Such a procedure allows for considerable increases in profitability by substantially reducing labor costs for corporations; at least for these corporations, the neoliberal idea of opening markets without restriction was a guaranteed winner. As these corporations grew with the opening up of markets, their influence on powerful states and entities within the broader international system simultaneously increased, allowing them to re-implant this ideology through the system of international institutions created to regulate trade and the global economy (Robinson and Harris 2000: 11-54).

At the level of global governance, this philosophy has manifested across international institutions. For example, the World Bank and IMF frequently attached conditionality to the loans they offered developing countries that demanded that these countries remove trade barriers and open up their markets to global corporations, often at considerable cost to local and national economies, for example during the Latin American Debt Crisis in the 1980s (Vetmeyer, Petras, and Vieux 2016). The World Trade Organization (WTO) similarly seeks to remove trade barriers by "reaching inside borders" to open up markets by creating subsidy controls, strengthening global intellectual property rights (including in critical and controversial areas in the medical field), and creating a binding dispute settlement mechanism with the possibility of sanctions for those who defy these rules (WTO 2019). Many prominent scholars, including Sara Dillon believe that such policies substantially damaged the livelihoods of poorer individuals in both developing and developed countries by removing necessary protections provided by the state and further concentrated wealth in the hands of the major global corporations who benefited from increased access to cheap labor and smooth capital movement (Dillon 2018: 1005). This turn towards neoliberalism in international institutions is frequently defined and discussed as the "Washington Consensus," as a result of the vital role the United States played in conceiving it; perceiving untrammeled and open markets as hugely advantageous to the huge corporations present within the United States (Williamson 2009: 7).

Along with the IMF and WTO, NAFTA is seen as a cornerstone of the global neoliberal order and will be the core institution focused upon in this study. The brainchild of the Reagan's administration, NAFTA was conceived with the idea of removing barriers to trade between the US, Canada, and Mexico to increase the efficiency of cross border transactions and therefore (at least in theory) create greater prosperity for all three countries. The deal was eventually signed into law after six years of intense negotiation. With the negotiations dominated by the interests of the United States, the three fundamental tenets of NAFTA closely align with the neoliberal philosophy espoused through the Washington consensus (Broad 2004: 129-154). Firstly, NAFTA grants "Most Favored Nation" status to all three participants, which means countries must give all parties equal treatment and thus cannot treat one country differently from another. This means they cannot give domestic companies better direct investment than foreign ones and, importantly, means that governments must offer federal contracts to companies in all three countries. Secondly, NAFTA eliminates virtually all tariffs between the three countries, meaning that governments cannot protect domestic industries by leveling tariffs against foreign products to protect produce from local companies, farms, or suppliers. Finally, NAFTA demands that patents produced in all three countries must be upheld universally by other members ("Nafta: Objectives"). Overall, then, we can see that the structure of NAFTA closely follows the pattern of neoliberalism - in terms of seeking to open up markets without restriction and removing any protections or subsidies for local industry or commerce. In terms of impact on Mexico, which will be the key focus of this study, NAFTA may have contributed to a modest increase in overall GDP (Hanson 2003). However, many have suggested that NAFTA has been instrumental in dividing Mexico into two, one part increasingly wealthy, corporate, and strongly benefiting from trade liberalization, and another, poorer Mexico, which has seen little of the benefit of this liberalization and, indeed in many cases has been actively harmed by the opening up of the Mexican economy to untrammeled competition from corporations in the United States, who often seek to exploit them (Immison 2017).

Unlike states which have a more comprehensive set of concerns including human rights and democracy, multinational corporations are almost solely concerned with profit maximization. Therefore individuals are reduced 
to economic units within the calculations of these economic behemoths; and they will generally choose to ignore or reject human rights norms if doing so makes the corporation more economically or financially efficient (Barfield 2001: 403). As Surya Deva points out, multinational corporations have been accused and convicted for every time of human rights violations imaginable under international law to maximize their profits (2003: 4). One particular egregious form of violation carried out by these corporations includes the unsafe dumping of toxic waste; for example, two oil spills from a Shell pipeline destroyed thousands of lives. Very frequently, human rights abuses and unethical business practices are carried out in developing countries by multinationals headquartered in developed countries due to the weaker legal protections and human rights law in said developing countries (Amnesty International: 2017).

Resultantly, the dominant form of capitalism unleashed by neoliberalism has the strong potentiality of dehumanizing those subject to its regimes. As neoliberalism emboldens corporations, they increasingly seek to work only within their company constitution and in the challenge to any state regulation, problems which are likely only to become worse. As well as weaker legal and political institutions within developing countries, those that exist tend to be more corrupt, allowing transnational corporations to leverage their considerable economic might to "buy" political and legal protection from states either through direct or indirect bribery and continue their relentless pursuit of profit relatively unopposed (Deva 2003: 4-8).

This article will now go on to look at a particular case study in which emergent neoliberal practice has led to the dehumanization of women by creating lawless economic spaces in which women are frequently subjects of violence. It will discuss how NAFTA, detailed above, has created uneven forms of development that prevented local Mexican factories from competing and instead of forcing Mexican women into maquiladoras, specifically designed factories owned by foreign corporations but operated on Mexican soil to reduce costs, made possible by NAFTA's removal of tariffs and protections from local industry. This has led to the reduction of Mexican women to economic units rather than human beings in possession of a full set of human rights and indeed in many cases their disappearances and deaths, supporting the assertions made in this introductory section and opening up important questions about the natural human consequences of Neoliberal globalism more widely.

\section{NAFTA and Femicides in Ciudad Juárez}

The Mexican metropolis of Ciudad Juárez is the largest city in the state of Chihuahua, with a population of almost 1.5 million. Juárez is a twin city of El Paso, Texas, with which it is connected by four international bridges that are vigilantly guarded by border patrol. The Río Grande river forms a natural US-Mexican border that splits the two cities. While El Paso belongs to one of the safest places to live in the US, Ciudad Juárez is regarded as one of the most dangerous cities in the world (Eastaugh 2018). Its high death toll has earned Juárez several unflattering nicknames over the years, from "murder city" or "the world's murder capital" to "the city where women disappear" and "the capital of murdered women" (COHA 2009). From 2009 to 2011, Ciudad Juárez dominated statistics as the most dangerous city in the world, excluding war zones (Driver 2015: xii). In 2008, the average number of dead bodies found each day was 4.4; in 2009 it was 7.5 and in 2010 disquieting 9.9.

Many of these murders have been femicides (Driver 2015: xiv). Femicide is generally defined as "the killing of a woman or girl, in particular by a man and on account of her gender" ("Femicide"). Jill Radford and Diana H. Russell extend this definition by pointing out that femicide is "often condoned by, if not sponsored, by the state and/ or by religious institutions" (quoted in full in Gaspar de Alba and Guzmán 2010: 1). In their study, they implicate Mexican government by showing how authorities derail the investigation of the Juárez femicides and downplay them by claiming that they are "an invention of some crazy feminists and the attention-grabbing mothers of a few dead prostitutes” (quoted in full in Gaspar de Alba and Guzmán 2010: 2). This official rhetoric is reinforced by a lack of data as many of the missing women also disappear from official registers. Unrecorded violence is then "seemingly invisible" (Driver 2015: 3). Kelliher explains that official records encompass only those bodies that have been discovered and exclude all those that are still missing.

Moreover, even this distorted number is further manipulated by the authorities (Kelliher 2015: 9). However, many members of the public challenge this deadly silence and, among other things, keep femicide records that range from 500 to 3000 since the year 1993. According to the National Citizen Femicide Observatory, six women are murdered every day in Juárez (López 2018). After 2010, which was the most violent year in the city's history, Juárez seemed to be finally dealing with its rampant criminality. However, after a few calmer years, the homicide rate 
skyrocketed again in 2016 and has been on the rise ever since. The year 2018 was especially violent, averaging as many as 15 murders on some days (Del Pozo 2018). The femicide rate increased as well, and the official number of 96 murders of women in 2017 left many inhabitants fearing that history may repeat itself (CEDAW 2018: 6). While the exact figures are debatable, researchers agree on one thing: while femicides certainly occurred before 1993 as well, their numbers skyrocketed after this year and, as female bodies started to appear in noticeable numbers in public places, Juárez began to face a femicide epidemic (Driver 2015: 18).

This upsurge in femicides coincides with the signing of the NAFTA by Mexico, the US, and Canada in 1992. This neoliberal agreement rapidly and drastically reshaped the Mexican economy, a change that called for a fundamental transformation of Mexican society. This paper will demonstrate that Mexico's inability to deal with this quick neoliberalization is one of the principal causes of the Juárez femicides. Furthermore, it will show that the exploitative nature of neoliberal capitalism that values profit more than human lives is another major factor that plays a significant role in the femicides.

The first critical change that commenced a chain of interrelated events contributing to the Juárez femicides was the reformation of the so-called ejido system in 1992. The ejido system refers to the communal ownership of arable land which came into effect after the Mexican revolution and ensured that land was kept in the community as it was protected by law from privatization and confiscation (Klein 2015: Loc. 209-10). This traditional Indigenous system was disrupted during the presidency of Carlos Salinas, who made amendments to the law which enabled the acquisition of communal lands by foreign corporations. These reforms came as a reaction to the NAFTA negotiations in 1992 as the ejido system did not correspond to the agreement's objectives (Klein 2015: Loc. 209-10). As a result, many rural farmers were left landless and jobless as they lost their means of subsistence. The figure of a displaced farmer became the new Mexican stereotype as whole families were forced to leave their traditional lands. In response to these dynamics, NAFTA promised prosperity and improvement of living standards and offered a seemingly ideal solution to the crisis (that it inflicted) by creating thousands of new jobs in newly built foreign factories-the maquiladoras.

Parallels exist between this process of essentially forcible expulsion of the Mexican rural peasantry towards urban centers and Karl Marx's discussion of land enclosure in the 18th and 19th centuries. In Chapter 27 of Das

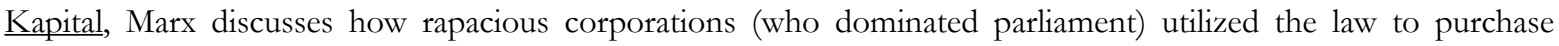
agricultural land compulsorily, thus forcing agricultural workers towards urban areas and the factories owned by the capitalist class in order to provide a cheap source of disposable labor (the proletariat) to keep the capitalist machine running (Marx 1867: Ch 27). These workers were enticed to the city with promises of a better life- but instead found ruthless exploitation, dehumanization and squalor when they arrived. As we will see in the analysis below, much the same could be said of the maquiladoras that sprung up in response to the creation of NAFTA's tariff-free zones.

Maquiladoras, also known as maquilas, are big assembly plants owned by wealthy transnational corporations that employ cheap foreign labor to assemble their products from imported materials only to be later exported back to the country of origin and sold for greater profit. After NAFTA established tariff-free zones between the US and Mexico, a large number of US-owned maquiladoras were constructed on the Mexican side of the border. Over 300 of these maquiladoras were built in and around Juárez following the signing, operated by companies such as Sony or IBM (Driver 2015: 18-19). The immediate impact that NAFTA had on both the national and international economy was enormous. As local factories could no longer compete on the Mexican market, many workers were forced to leave their homes in search of a new job in maquiladoras (COHA 2009). Since NAFTA made it hard for southern peasants who had lost their land to self-sustain themselves, their immigration to the north of Mexico occurred as a means of survival.

Nonetheless, not all of the displaced workers found the promised employment in the transformed industrial north as their numbers far exceeded the numbers of available positions. Having more workers than could be accommodated is advantageous to employers as it gives them the chance to pick the most suitable candidates and, above all, to ignore labor rights. Substantial evidence exists that highlights the interrelation between the numbers of employees and their rights; that is, more workers means fewer rights. It is far more profitable to exploit the workers than to treat them with the respect they deserve (Otero 2011: 385). NAFTA, as a neoliberal agreement aimed at increasing economic prosperity, however, at the expense of generating exploitation in the Mexican market.

The most suitable candidates for labor positions in maquiladoras showed to be women. Taylor contends that employers look for "docile, undemanding, nimble-fingered, nonunion" workers (quoted in full in Gaspar de Alba and Guzmán 2010: 127). As such characteristics are stereotypically attributed to women, corporations filled their 
assembly plants with young female workers who are capitalized on and exploited. On average, they stay in the job for five years before being "disposed of" and replaced by their younger and more dexterous counterparts who are, for the time being, are more valuable as they generate more profit (Reinares 2010: 64). Not only do maquiladora workers have to endure inhuman working conditions, but they are also subjected to sexual abuse as their reproductive cycles are routinely checked. To secure their employment, women are required to present bloody tampons every month. As soon as a woman is suspected of pregnancy, she loses her job. At the same time, male supervisors who have been reported to sexually abuse female workers, are often those responsible for their pregnancy and subsequent dismissal (Gaspar de Alba and Guzmán 2010: 127).

However, maquiladora workers' vulnerability extends beyond the plants where their economic exploitation translates into a serious life risk as these women are constrained to walk alone at night from and to work in dangerous zones of Juárez (Driver 2015: 1). A typical femicide victim is generally described as a young, poor, dark-skinned woman who migrated to the city from the south to work in a maquiladora (Gaspar de Alba and Guzmán 2010: 1). Alternatively, in Amnesty International's words, "young women with no power in society, whose deaths have no political cost for the local authorities" (2003: 2). This serious threat to the maquiladora workers' lives is ignored not only by their employers but also by law enforcement and the state. Their disappearance and murders get primarily overlooked on both sides of the border as poor Mexican women's bodies are viewed as disposable in a neoliberal era where profit is valued more than their lives. In her study, Camelia Raghinaru critiques the neoliberal world that reduces marginalized women to "cheap, unskilled labor that is easily disposable" (2016: 157). She argues that neoliberal development goes hand in hand with the marginalization of minorities and that apart from being exploited, maquiladora victims are "completely excluded as the waste of contemporary postcolonialism" (Raghinaru 2016: 148).

Similarly, Laura Reinares affirms that "bourgeois privileges in the global North ... are built upon the literal sacrifice of a disposable female workforce” (2010: 64). She links Karl Marx' theoretical analysis of the exploitation of seasonal workers who are entirely ruled by the market's needs with the disposal of female bodies. Once a woman loses her ability to work as effectively as her younger co-worker, she stops being valued and is soon "disposed of" (Reinares 2010: 53). The class conflict between the bourgeoisie and the proletariat, as explained by Marx, can be extended to include race and gender within the US-Mexican border context. Robert Mize explains that neoliberalism in the US-Mexico border context is highly gendered because the majority of maquiladora laborers are women, and racialized because it is mostly white people who benefit from the free-trade (2008: 143-144). Arguably, the racial aspect of neoliberalism might change over time with the estimated growth of Latinx ${ }^{1}$ or mixed-race population in the US. At least for now, however, neoliberalism mostly benefits the white population.

Femicide victims are usually found with their bodies mutilated and violated, which indicates brutal torture, sexual abuse, and strangulation. López points out that their breasts are often cut off, which further points to the fact that gender is the main factor in these crimes. Many popular theories exist as to who benefits from the femicides, among which snuff film and organ harvesting theories remain the most stereotypical and persisting ones (Driver 2015: 22). However, while some of the victims may have been used for snuff films and/or organ harvesting, these are unlikely to be the primary or the only reasons for their murders but rather the result of capitalist resourcefulness, that is, making as much profit from the women as possible. Gaspar de Alba points out, " $[\mathrm{t}]$ he irony of it: an assembly worker disassembled in the desert" (2007: 255). The paradox is evident: the same women who assemble great numbers of products for the use of privileged middle-class consumers also serve as involuntary organ donors for the same group of people whose lives are considered worthier in this neoliberal era. Furthermore, violence is treated as a mere secondary effect that is somewhat unpleasant but not enough to be taken seriously and that only upsets part of a population.

Mexican women's increased vulnerability after the signing of NAFTA can also be connected to the elevated anti-immigration sentiments in the US that the agreement provoked. In his study on NAFTA's impact on migration, Gerardo Otero connects Mexican immigration to the US with the loss of labor sovereignty generated by NAFTA, in other words, Mexico's new dependency on its northern neighbor for both food and employment has led to a growing emigration as Mexico lost the ability to provide decently paid jobs for most of its population (Otero 2011: 385). Thus, those who failed to find a job on the Mexican side of the border decided to try their luck on the opposite bank of Rio Grande. However, as NAFTA made it harder for people to cross the borders, many immigrants have been forced to immigrate undocumented. Instead of accepting economic refugees after taking their means of subsistence away from them, the US treats them as the so-called illegal aliens (Mize 2008: 144). Racial profiling on the 
militarized US-Mexican border is a prevalent issue that under the Trump administration has only intensified. Robert Mize uses the term "neoliberal nativism" to explain how neoliberalism, and more specifically NAFTA, defines the US-Mexican border region as raced, classed, and gendered (2008: 136). The term "neoliberal nativism" is defined by Mize as the meeting of "the political economy of free trade ideology [and] the state-sanctioned violence" (Mize 2008: 136). While NAFTA helped the free flow of commodities, it restricted the movement of people. Mize argues that neoliberal nativism leads to border militarization, the racialization of Mexicans, criminalization of "illegal aliens," class marginalization, labor exploitation, racial profiling, and increased endangerment of Mexican women and children (Mize 2008: 140).

Similarly, Gaspar de Alba connects the femicides of pregnant women with anti-immigration sentiments in the US society. Pregnant women's economic exploitation has already been discussed; however, losing their job is only the first sign of their increased precariousness. Gaspar de Alba explains that when a woman loses her job in a maquiladora, her biggest chance for a decent life is emigration: "they can get pregnant, and that's the threat they pose when they come this close to the border. Call it a side effect of NAFTA that has to be curtailed by whatever means possible" (Gaspar de Alba, Desert Blood 2007: 254, original emphasis). Gaspar de Alba suggests that NAFTA did not limit the immigration of Mexican women and children to the US, which is widely perceived as problematic. She echoes Leo Chávez' theory of the Latina threat. In his paper, Chávez discusses how Latina reproduction and fertility have been constructed as threats to American society. The paper demonstrates that "antiimmigrant sentiment, especially during the 1980s and 1990s, focused specifically on the reproductive capacities of a Mexican immigrant and Mexican-origin (U.S.-born) women" (Chávez 2004). As expected, Chávez’ findings prove that Latina's “differences from Anglo women [regarding reproduction] were insignificant” (2004: 173). Nevertheless, these facts remain overshadowed by anti-immigrant propaganda, the sentiments that Gaspar de Alba reflects in her work: "More illegal Mexican women in El Paso means more legal brown babies. Who wants more brown babies as legal citizens of the Promised Land?" (Desert Blood 2007: 332). She thus proposes that Mexican women are killed, together with their unborn children, to prevent their immigration to the US.

Finally, Mexican society's inability to adapt to the fast economic transitions inflicted by NAFTA has been foreshadowed as a factor that plays a significant role in the femicides. Gaspar de Alba diagnoses Mexican society with what she terms "the Tres Marías Syndrome" (Gaspar de Alba and Guzmán 2010: 81). She explains that in Mexican culture, it is believed that a woman represents one of the three biblical Marys, either the Virgin Mary, the Mother Mary, or Mary Magdalena, the prostitute. La Malinche also referred to as "La Chingada" (the fucked one) who is viewed as the traitor of Mexico, is said to be Mary Magdalena's descendant. Mexican women are expected to aspire to represent the first two Marys and thus have to obey a strict patriarchal code of ethics. The Virgin is expected to be innocent and obedient, to dress appropriately and discreetly, to live with her family until her wedding and to abstain from all sexual activities. The Virgin Mary then becomes the Mother Mary whose only function in life is to care for her family and renounce all other pleasures, including sexual activities with another purpose than to procreate. By contrast, Mary the prostitute is disobedient, promiscuous, humiliates her family, uses contraception, and enjoys sex. Moreover, she is the one who demoralizes men and therefore "deserves what she gets" (Gaspar de Alba and Guzmán 2010: 81-82).

Reinares also elaborates on the role of women in Mexican society. A woman's place is at home where she is expected to take care of her husband or her father, and the femicide victims are therefore seen as women who "have transgressed established social norms" (2010: 59). Violence on women is thus viewed as their punishment by both the authorities and the public. As the Chihuahuan state attorney general infamously remarked in 1999, "it is impossible not to get wet when you go outside in the rain; it is also impossible for a woman not to get killed when she goes out alone at night" (quoted in full in Gaspar de Alba and Guzmán 2010: 131). The attorney general's parallel implies that there is nothing the authorities can do to stop the murders, just like they cannot control the weather. No one is held responsible for the murders except for the victims themselves.

There is abundant evidence that the Mexican authorities adopted the attorney generals rhetoric of blaming the victim. Numerous testimonies from the grieving relatives of the missing women reveal the same pattern. The authorities told José Luis Castillo that his missing daughter must have been "hanging out with the wrong crowd" (quoted in full in Del Pozo 2018). They followed the usual narrative and insinuated that she was responsible for her own disappearance. Similarly, Suárez Padilla's daughter who was violently murdered by her ex-boyfriend was blamed by the police because "her cell phone contained 200 nude photos taken by the killer" who escaped punishment despite confessing (Matloff 2015). According to local activist group statistics, almost 100 young people have gone 
missing in 2018 and nobody has been apprehended (Del Pozo 2018). Most cases are not adequately investigated, and those few that lead to trial are rarely sentenced which makes Juárez the perfect place for perpetrators of all kinds (Kelliher 2018: 10). ${ }^{2}$

Most often, impunity and corruption are blamed for this inadequate official response. Staudt and Campbell state that in the Mexican context impunity should be understood as a "codeword for inept, incompetent and/or complicit law enforcement personnel and institutions at the municipal and state levels of Mexican society" (2008). More than often, reports, as well as the actual evidence, are mishandled by the Mexican police, making it impossible for world experts to investigate the crimes (Staudt and Campbell 2008) further. Former Mexican government representative Marcela Legarde confirmed widespread corruption in Mexican higher circles when she accused them of complicity by defining femicide as "a crime of the state which tolerates the murders of women and neither vigorously investigates the crimes nor holds the killers accountable" (quoted in full in Carrillo 2015). The sharp increase in the femicide rate in the last few years has provoked human rights organizations to further examine the Mexican government's inadequate actions which are documented in a report released by the Committee on the Elimination of Discrimination against Women (CEDAW 2018). The state has been accused of violation of its obligations to address the epidemic of femicides and for providing an appropriate context for the crimes that are on the rise (CEDAW 2018: 5). Accepting violence as an inevitable part of life in Juárez and failing to provide a proper official response to the femicides further perpetuates the victim-blaming rhetoric.

The cultural clash between American and Mexican values that is at least partially responsible for the outburst of gender violence was inevitable after the neoliberal transformation of patriarchal Juárez. When female workers became favored by maquiladora employers, the patriarchal system was under threat which stirred resentment in men who blamed women for their suddenly changed societal role (Gaspar de Alba and Guzmán 2010: 127). For the first time, women became the breadwinners while many men remained unemployed. Gaspar de Alba writes that "Juárez is not ready for the liberated woman, at least not in the lower classes. Their traditions are being disrupted in complete disproportion to changes in their economic status" (Desert Blood 2007: 252). As a consequence, working women are disrespected by men and seen as deserving of their tragic fate. It is apparent that Gaspar de Alba does not argue for the reaffirmation of machismo and patriarchy, but explains that forcing one's cultural values onto others only reinforces paternalistic attitudes.

The perception and treatment of female maquiladora workers are not dissimilar to that of sex workers. Naturally, city officials took advantage of the disillusionment among Juárez inhabitants and reinforced this public discourse by claiming that the murdered women-led "a double life," i.e., work both in maquiladoras and as sex workers (quoted in full in Gaspar de Alba and Guzmán 2010: 131). While this is true for only a small number of women, it is worth acknowledging the link between both occupations. Cepeda and Nowotny's study reveals that most women in Juárez become sex workers out of financial necessity. Similarly to women employed in maquiladoras, the majority of sex workers also came to Juárez from the south of Mexico or other Central American countries in the hope for a more comfortable life. As many were unable to secure employment at the competitive job market, sex work remained as the last option of how to stay financially independent (Cepeda and Nowotny 2014: 1509). The most striking aspect of this analysis is that female (sex) workers' lives are seen as less worthy and even deserving of the violent death that many encounter.

Thus, it comes as no surprise that there is little concern for both maquiladora and sex workers' rights protection. Elvia Arriola links NAFTA to the indifference towards women by pointing out that the neoliberal agreement protects transnational corporations "from being held accountable for any harm done to workers in Mexico" (quoted in full in Kelliher 2018: 9). Lack of labor rights for maquiladora workers translates to a lack of respect for women in general despite the significant role they have played in the city's expansion. Melissa Wright writes that the city's economic prosperity has always been linked to women workers, be it those working in factories or in the streets (2004: 369). Hence, for the longest time, a visible female presence was welcome as it was seen as a symbol of development, especially in the eyes of foreign investors and visitors to the city.

This perception has, however, shifted in recent years as female (sex) workers began to be wrongfully associated with "economic stagnation and social degradation" (Wright 2004: 370). Wright's study unmasks the city officials" complicity by providing a compelling analysis of how the city regulates female bodies and puts (sex) workers' lives at risk (2004). She explains that as a response to international criticism and a decline in corporate investment, the city elites decided to eliminate the once desirable female presence from the streets to give an impression of a middleclass urban environment (Wright 2004: 370). Sex workers have been impacted in particular by this new strategy as 
they now receive even less protection. Cepeda and Nowotny's research confirms that the frequency and severity of violence inflicted on sex workers in Juárez is dependent on location, i.e., official venues in downtown areas where sex work is quasi-legal tend to be safer than parts where sex work is illegal and often carried out in places such as cars, hotels, or dark alleys (2014: 1518).

One strategy employed by the police to eliminate female presence in the city was making sex work illegal in places where their presence was no longer desirable. The other strategy involves "such practices as kidnapping and harassment" (Wright 2004: 370). The official discourse "that equates any form of women's vanishing from public space with urban development and industrial progress" (Wright 2004: 370) not only reinforces the widespread rhetoric that sees women as second-class citizens but also encourages perpetrators to commit femicides that they may even consider as a service to the city. The circle of people complicit in the crimes continually expanding.

Finally, while it is beyond the scope of this paper to address the complexities of the drug war in Juárez, it is imperative to acknowledge its impacts on femicide rates. Like unregulated free trade, the drug war contributes to the creation of an environment that facilitates femicides. Gender violence is overlooked as a minor problem by governments on both sides of the border that like to make the war on drugs seem their top priority. As Kelliher contends, the government's military response "has both normalized violence and diverted attention from ... violence towards women" that is rendered invisible as a consequence (2018: 10). Moreover, despite the government's reluctance to recognize this, it is the poor sector of Mexican society that is most often targeted by the drug cartels, making women even more vulnerable because of the intersection of their class and gender (Kelliher 2018: 10). Finally, Wright reveals that authorities have adopted the victim-blaming rhetoric that they use as a justification for femicides to explain the high numbers of civilians who died as a consequence of the war on drugs (quoted in full in Kelliher 2018: 10). Such disclosure further points to the high levels of impunity and corruption in Mexican higher circles whose behavior alone implicates them in the crimes.

\section{Conclusion}

Women in post-NAFTA Juárez are in a paradoxical situation. The city they inhabit is both an attractive and to-be-avoided-at-all-costs place. Most of them escaped to the north to survive but ran into a death-trap instead. Furthermore, as workers, they are both desired and condemned. The intersection of their gender, race, and class makes them vulnerable in this neoliberal world where profit means more than anything else and where big transnational corporations have political power and authorities protect their interests. As a result, workers are objectified as cheap labor and dehumanized in the process of becoming victims of violence which has emerged as a side-effect of neoliberalism. The femicides hare overlooked because the sacrifice of maquiladora workers bolsters neoliberal capitalism. To end the violence, misogyny and exploitation of marginalized workers have to be stopped. However, such a change is difficult in a world governed by the neoliberal market, which has exploitation at its core.

Mexico, with its still very traditional society, serves as an ideal neoliberal colony as patriarchy is the driving force of neoliberalism. Alternatively, in the words of Gloria Anzaldúa, "the US.-Mexican border es una herida abierta where the Third World grates against the first and bleeds" (1987: 3). In the context of Juárez, this bleeding is very literal.

\section{Endnotes}

1. Latinx refers to "a person of Latin American origin or descent (used as a gender-neutral or non-binary alternative to Latino or Latina)" ("Latinx")

2. The National Citizen Femicide Observatory states that only about 1,6 percent of all investigated cases lead to sentencing (Matloff 2015). 


\section{References}

Amnesty International. “Corporate Accountability." www. amnesty.org. Accessed Feb 23, 2017.

Amnesty International. 2003. "Mexico Intolerable Killings: Ten Years of Abductions and Murders in Ciudad Juárez and Chihuahua." www.amnestyinternational.com. Accessed January $22,2019$.

Anzaldúa, Gloria. 1987. Borderlands = La Frontera: The New Mestiza. San Francisco: Aunt Lute books.

Barfield, Claude E., 2001. Free Trade, Sovereignty, Democracy: Future of the World Trade Organization. DC: AEI Press.

Broad, Robin. 2004. "The Washington consensus meets the global backlash: shifting debates and policies." Globalizations 1.2:129-154.

Carrillo, Karol Alejandra Arambula. 2015. "Femicide in Mexico: An unpunished Crime.” feministing.com. Accessed 17 April 2019.

CEDAW. 2018. "Alternative Report on Violence against Women in Ciudad Juarez, Chihuahua, Mexico.” tbinternet.ohchr.org. Accessed 17 April 2019.

Cepeda, Alice, and Kathryn M. Nowotny. 2014. "A Border Context of Violence: Mexican Female Sex Workers on the U.S.Mexico Border." Violence Against Women 20(12):1506-1531.

Chávez, Leo, R. 2004. "A Glass Half Empty: Latina Reproduction and Public Discourse." Human Organization 63(2):173-188.

Chorev, Nitsan, and Sarah Babb. 2009. “The Crisis of Neoliberalism and the Future of International Institutions: A Comparison of the IMF and the WTO." Theory and society, $38(5): 459-484$.

COHA. 2009. "Femicides of Juárez: Violence Against Women in Mexico.” www.coha.org. Accessed March 1, 2018.

Deva, Surya. 2003. "Human rights violations by multinational corporations and international law: were from here." Conn. J. Int'l L.19:1-57.

Del Pozo, Melissa. 2018. “Temen que se repita la historia de terror." www.milenio.com. Accessed 17 April 2019.

Dillon, Sara. 2013. “Opportunism and Trade Law Revisited: The Pseudo-Constitution of the WTO.” BC Int'l \& Comp. L. Rev 36:1005.

Driver, Alice. 2015. More or Less Dead: Feminicide, Haunting, and the Ethics of Representation in Mexico. Tucson: UA Press.

Eastaugh, Sophie. 2018. "The Future of the US-Mexican Border: Inside the 'Split City' of El Paso-Juárez.” www.guardian.com. Accessed March 1, 2018.
Fukuyama, Francis. 1989. "The end of history?." The national interest 16:3-18. "Femicide." Noun. www.oxforddictionaries. com. Accessed March 28, 2019.

Gaspar, de Alba, Alicia. 2007. Desert Blood: The Juarez Murders. Houston: Arte Publico.

Gaspar, de Alba, Alicia., and Georgina Guzman. 2010. Making a Killing: Femicide, Free Trade, and La Frontera. Austin: University of Texas.

Hanson, Gordon H. 2003. "What has happened to wages in Mexico since NAFTA?.” www.nber.org. Accessed April 28, 2019.

Harvey, David. 2007. "Neoliberalism as creative destruction.” The annals of the American academy of political and social science 610(1):21-44.

Hayek, Friedrich August. 1980. Individualism and economic order. Chicago: $U$ of Chicago.

Immison, Paul. 2017. "How NAFTA Explains the Two Mexicos" www.theatlantic.com. Accessed April 28, 2019.

Kelliher, Meaghan. 2015. "Femicide in Ciudad Juarez." Kaleidoscope Journal 7(1):8-39.

Klein, Hilary. 2015. Compañeras: Zapatista Women's Stories. New York: Seven Stories. Kindle.

Kostova, Tatiana, Kendall Roth, and M. Tina Dacin. 2008. "Institutional theory in the study of multinational corporations: A critique and new directions." Academy of management review 33(4):994-1006.

López, María Encarnación. 2018. "Femicide in Ciudad Juárez Is Enabled by the Regulation of Gender, Justice, and Production in Mexico." www.lse.co.uk. Accessed January 22, 2019.

Marx, Karl. 1867. Das Kapital. www.marxists.org. Accessed April $28,2019$.

Matloff, Judith. 2015. "Six women murdered each day as femicide in Mexico nears a pandemic" america.aljazeera.com. Accessed 17 April 2019.

Mize, Ronald L. 2008. "Interrogating Race, Class, Gender and Capitalism Along the U.S.-Mexico Border: Neoliberal Nativism and Maquila Modes of Production." Race, Gender \& Class 15(1/2):134-55.

Monbiot, George. 2016. "Neoliberalism-the ideology at the roots of all our problems" www.theguardian.com. Accessed Feb 23, 2017.

"Nafta: Objectives." www.nafta-sec-alena.org. Accessed April 28, 2019. 
Neate, Rupert. 2017. "Richest $1 \%$ own half the worlds wealth, Study Finds” www.theguardian.com. Accessed Feb 24, 2017.

Otero, Gerardo. 2011. "Neoliberal Globalization, NAFTA, and Migration: Mexico's Loss of Food and Labor Sovereignty." Journal of Poverty 15(4):384-402.

Palley, Thomas I. 2005. "From Keynesianism to Neoliberalism: Shifting Paradigms in Economics." Pp. 20-29 in Neoliberalism: A critical reader, edited by A. Saad-Filho, and D. Johnston. London: Pluto Press.

Quintana, Marti. 2018. "Mexican Women Take Action Against Growing Number of Femicides.” www.efe.com. Accessed 17 April 2019.

Raghinaru, Camelia. 2016. "Biopolitics in Roberto Bolaño's 2666, 'The Part About the Crimes." Other Modernities 15:146-162.

Ramirez, Miguel D. 1993. "Stabilization and adjustment in Latin America: a neostructuralist perspective.” Journal of Economic Issues 27(4):1015-1040.

Reinares, Laura Barberán. 2010. "Globalized Philomels: State Patriarchy, Transnational Capital, and the Femicides on the US-Mexican Border in Roberto Bolaño's 2666." South Atlantic Review 75(4):51-72.
Robinson, William I., and Jerry Harris. 2000. “Towards a Global Ruling Class? Globalization and the Transnational Capitalist Class." Science \& Society 64(1):11-54.

Rodrik, Dani. 2017. "Rescuing Economics from Neoliberalism." Boston Review 6: pp.6-10.

Staudt, Kathleen, and Howard Campbell. 2008. "The Other Side of the Ciudad Juárez Femicide Story." Violence: A Daily Threat (Winter):np.

Veltmeyer, Henry, James Petras, and Steve Vieux. 2016. Neoliberalism and Class Conflict in Latin America: A comparative perspective on the political economy of structural adjustment. Springer.

Williamson, John. 2009. "A short history of the Washington Consensus.” Law \& Bus. Rev. Am. 15:7.

Wright, Melissa W. 2004. "From Protests to Politics: Sex Work, Women's Worth, and Ciudad Juarez Modernity." Annals of the Association of American Geographers 94(2):369-386.

WTO. www.wto.org. Accessed April 28, 2018. 